\title{
Challenges and pitfalls in diagnosis of Parosteal Osteosarcoma: A clinicopathologic study of 23 cases
}

\author{
Muhammad Usman Tariq* ${ }^{* 1}$, Nasir Ud Din ${ }^{1}$, Arsalan Ahmed ${ }^{1}$, Shahid Pervez ${ }^{1}$, Romana Idrees ${ }^{1}$, Saira Fatima ${ }^{1}$, \\ Masood Umer ${ }^{2}$, Naila Kayani ${ }^{1}$ \\ ${ }^{1}$ Department of Pathology and Laboratory Medicine, Aga Khan University Hospital, Karachi, Pakistan \\ ${ }^{2}$ Department of Orthopedic Surgery, Aga Khan University Hospital, Karachi, Pakistan
}

Received: October 27, 2015

Accepted: Feburay 18, 2016

Online Published: March 31, 2016

DOI: $10.5430 /$ jst.v6n2p17

URL: http://dx.doi.org/10.5430/jst.v6n2p17

\begin{abstract}
Objective: Parosteal Osteosarcoma (PO) is an uncommon variant of osteosarcoma. Diagnosing PO is important due to its malignant nature but the diversity of histologic features makes it challenging by adding a number of soft tissue, bony and cartilaginous lesions into the list of differential diagnosis. Our aim was to study the clinicopathologic and histological features of PO with emphasis on features helpful in its discrimination from other mimicking lesions.

Methods: We reviewed 23 cases of PO diagnosed in our institution between January 2001 and August 2015.

Results: Femur was the most commonly involved bone $(68.2 \%)$ along with other long bones and rib in a single case. Soft tissue component was graded as Grade1 in 9(39\%), Grade2 in 8(34.7\%) and Grade3 in 4(17.3\%) cases. Bony component was seen either in combination of or exclusively as parallel streams and interconnected trabeculae (mosaic-pattern). Out of 9 cases with cartilage component, 3 showed a cartilage cap. $2(8.6 \%)$ cases showed dedifferentiation into osteosarcoma.

Conclusion: PO should always be considered in the differential diagnosis of every lesion arising from the bone surface. Knowledge of the variations in histologic features helps to reach the correct diagnosis which should never be made without radiological correlation.
\end{abstract}

Key Words: Parosteal, Juxtacortical, Osteosarcoma, Cartilage cap, Dedifferentiated

\section{INTRODUCTION}

Parosteal Osteosarcoma (PO) is the most common surface osteosarcoma which arises from the soft tissue in the immediate vicinity of periosteum. It comprises $4.8 \%$ of all osteosarcomas and $1.7 \%$ of all malignant tumors of bone. ${ }^{[1]}$ It can occur over a wide age range of 9 to 62 years with peak incidence in 3rd decade and male to female ratio of 2:3. ${ }^{[2-4]}$ Femur is involved approximately in $70 \%$ cases followed by proximal tibia and proximal humerus. ${ }^{[5,6]} \mathrm{PO}$ generally presents as a painless swelling which grossly appears as a well-defined ossified sessile growth arising from the bone surface. ${ }^{[7-10]}$ Cut surface varies from gray white fibrous, cartilagenous to hard, depending upon the proportion of its histologic components. ${ }^{[11]}$ Microscopically, presence of soft tissue and bony components is integral to the diagnosis of this entity. ${ }^{[12,13]}$ The soft tissue component presents in different histologic grades and the bony component can present in a variety of morphologic forms, whose combinations mimic a number soft tissue, fibro-osseus and bony lesions of reactive and neoplastic and nature. ${ }^{[2-4,10]}$ Moreover, the presence of cartilaginous component further increases the diagnostic challenge by adding cartilaginous tumors to the differential diagnosis. ${ }^{[1,9,14,15]}$ Like soft tissue tumors of other lineages, the phenomenon of dedifferentiation is also observed in PO.

\footnotetext{
* Correspondence: Muhammad Usman Tariq; Email: mohammad.usman@aku.edu; Address: Section of Histopathology, Department of Pathology and Laboratory Medicine, Aga Khan University Hospital, Stadium Road, Karachi, Pakistan.
}

Published by Sciedu Press 
Distinction of this tumor from the mimics of benign and reactive nature becomes crucial due to its malignant potential. Apart from the peculiar radiological appearance, in depth knowledge of the morphologic features is also necessary for reaching the accurate diagnosis. ${ }^{[14]}$

Our aim was to study the clinicopathologic and histological features of Parosteal osteosarcoma with emphasis on features helpful in its discrimination from other mimicking conditions.

\section{MATERIALS AND METHODS}

We retrieved 23 cases of PO from the surgical pathology database of Section of Histopathology, Aga Khan University Hospital reported between January 2001 and August
2015 through "Integrated Laboratory Management System (ILMS)" software. Since this was a retrospective study and did not involve actual identification of patients, approval from the Hospital Ethical Review Committee was exempted. Clinical information regarding age, sex, location, presenting complaints and tumor size was obtained from the pathology reports. H\&E stained microscopic glass slides were reviewed by two pathologists (Tariq MU and Din NU) to assess histological features of soft tissue, bony and cartilage components. Tumors were labeled as "Dedifferetiated" when conventional low grade tumor abruptly transformed into high grade sarcomatous areas of any differentiation. ${ }^{[16]}$ Follow up information was taken from the patients via telephonic communication.

Table 1. Summary of clinicopathological features and follow up information of parosteal osteosarcoma patients $(\mathrm{n}=23$ )

\begin{tabular}{|c|c|c|c|c|c|c|c|c|c|}
\hline $\begin{array}{l}\text { Case } \\
\text { No. }\end{array}$ & $\begin{array}{l}\text { Age } \\
\text { (Yrs) }\end{array}$ & Sex & Site & $\begin{array}{l}\text { Histologic } \\
\text { grade }\end{array}$ & $\begin{array}{l}\text { Surgical } \\
\text { Procedure }\end{array}$ & Chemotherapy & $\begin{array}{l}\text { Recurrence/ } \\
\text { Metastasis }\end{array}$ & $\begin{array}{l}\text { Alive/ } \\
\text { Dead }\end{array}$ & $\begin{array}{l}\text { Follow up duration } \\
\text { and Disease Free } \\
\text { Survival (DFS) }\end{array}$ \\
\hline 1 & 26 & $\mathrm{~F}$ & Radius & Grade 1 & $\begin{array}{l}\text { Local } \\
\text { excision }\end{array}$ & Received & $\begin{array}{l}\text { Recurrence } 2 \times \& \\
\text { Lung metastasis }\end{array}$ & Died & $\begin{array}{l}146 \text { months } \\
\text { (DFS=108 months)* }\end{array}$ \\
\hline 2 & 21 & $\mathrm{~F}$ & Femur & Grade 1 & Not known & Not known & Not known & Not known & Not known \\
\hline 3 & 16 & M & Femur & Grade 1 & Not known & Not known & Not known & Not known & Not known \\
\hline 4 & 22 & M & Femur & Grade 2 & Not known & Not known & Not known & Not known & Not known \\
\hline 5 & 20 & M & Tibia & Grade 3 & Not known & Not known & Not known & Not known & Not known \\
\hline 6 & 21 & $\mathrm{~F}$ & Femur & Grade 2 & Not known & Not known & Not known & Not known & Not known \\
\hline 7 & 25 & M & Femur & Grade 3 & $\begin{array}{l}\text { Local } \\
\text { excision }\end{array}$ & Not received & None & Alive & 49 months \\
\hline 8 & 29 & M & $\begin{array}{l}\text { Not } \\
\text { mentioned }\end{array}$ & Grade 3 & Not known & Not known & Not known & Not known & Not known \\
\hline 9 & 18 & $\mathrm{~F}$ & Femur & Grade 1 & $\begin{array}{l}\text { Local } \\
\text { excision }\end{array}$ & Received & None & Alive & 48 months \\
\hline 10 & 33 & M & Femur & Grade 1 & Amputation & Not received & Recurrence & Alive & $\begin{array}{l}60 \text { months } \\
\text { (DFS = } 2 \text { months)* }\end{array}$ \\
\hline 11 & 28 & $\mathrm{~F}$ & Humerus & Grade 2 & Not known & Not known & Not known & Not known & Not known \\
\hline 12 & 22 & $\mathrm{~F}$ & Femur & Grade 2 & Amputation & Not received & None & Alive & 38 months \\
\hline 13 & 25 & M & Tibia & Dedifferentiated & Amputation & Received & None & Alive & 31 months \\
\hline 14 & 22 & $\mathrm{~F}$ & Femur & Grade 1 & $\begin{array}{l}\text { Not } \\
\text { performed }\end{array}$ & Not received & None & Alive & 30 months \\
\hline 15 & 20 & $\mathrm{~F}$ & Tibia & Grade 1 & Not known & Not known & Not known & Not known & Not known \\
\hline 16 & 34 & $\mathrm{~F}$ & Femur & Grade 2 & $\begin{array}{l}\text { Not } \\
\text { performed }\end{array}$ & Not received & None & Alive & 25 months \\
\hline 17 & 35 & $\mathrm{~F}$ & Femur & Grade 1 & Amputation & Received & None & Alive & 21 months \\
\hline 18 & 23 & M & Femur & Grade 1 & $\begin{array}{l}\text { Local } \\
\text { excision }\end{array}$ & Received & None & Alive & 20 months \\
\hline 19 & 25 & $\mathrm{~F}$ & Fibula & Grade 2 & $\begin{array}{l}\text { Local } \\
\text { excision }\end{array}$ & Received & Recurrence & Alive & $\begin{array}{l}86 \text { months } \\
\text { (DFS = } 77 \text { months)* }\end{array}$ \\
\hline 20 & 61 & $\mathrm{~F}$ & Femur & Grade 2 & Not known & Not known & Not known & Not known & Not known \\
\hline 21 & 45 & $\mathrm{~F}$ & Rib & Grade 2 & Not known & Not known & Not known & Not known & Not known \\
\hline 22 & 30 & $\mathrm{~F}$ & Femur & Dedifferentiated & Amputation & Received & None & Alive & 14 months \\
\hline 23 & 27 & M & Femur & Grade 2 & Not known & Not known & Not known & Not known & Not known \\
\hline
\end{tabular}

Note. $*$ DFS = Disease Free Survival; interval between surgical procedure and recurrence.

\section{RESUlts}

Mean age of presentation was $26.3 \pm 9.6$ years and $\mathrm{M}: \mathrm{F}$ ratio was $1: 1.55$. Femur was involved in $68.2 \%$ cases. Radiologically, tumors appeared as densely ossified, lobulated masses with irregular margins. An intact radiolucent zone was also appreciated between the tumor and underlying uninvolved cortex (see Figure 1). Follow up duration ranged from 3 to 146 months with mean $\pm S D$ of $47.3 \pm 37$ and median of 42 months. Recurrence was observed in 3 (25\%) patients (after 2, 77 and 108 months) and lung metastasis was seen 
in a single case (after 108 months). All of the patients were alive except for a single patient who died of disease after 12 years (see Table 1).
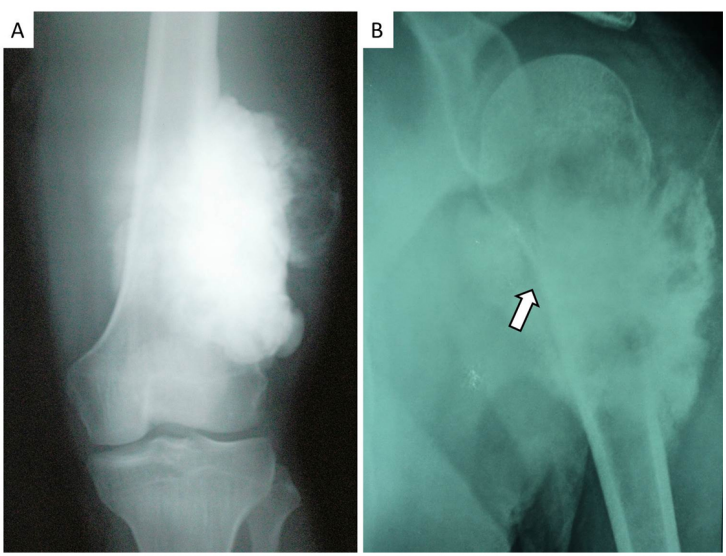

Figure 1. Plain radiograph findings. A) A densely ossified, lobulated mass with irregular margins arising from the distal femur; B) Lesion arising from proximal humerus with similar features. The underlying uninvolved cortex is intact (arrow head).

\subsection{Soft tissue component}

Soft tissue component comprised of fascicles of spindle shape cells which were graded from 1 to 3 according to the criteria used by Campanacci M et al. ${ }^{[3]}$ (see Figure 2, A-C). Dedifferentiation was observed in 2 cases. The background stroma was predominantly hyalinized and myxoid change in the background stroma was observed in only 2 cases. In 5 cases, the soft tissue component was quiet prominent and presented as separate hypocellular nodules of spindled cells in a hyalinized stroma devoid of any bony or cartilage component. 3 cases also exhibited hemangiopericytoma-like vessels. The proliferation of the soft component resulted in the entrapment of surrounding adipose tissue and muscle fibers (see Figure 2, D-F).

Dedifferentiated cases showed osteosarcomatous differentiation which was osteoblastic in one and chondroblastic in the other case. Both of these cases showed conventional PO with grade 2 soft tissue component and parallel streams of lamellar bone (see Figure 3 and Table 2).
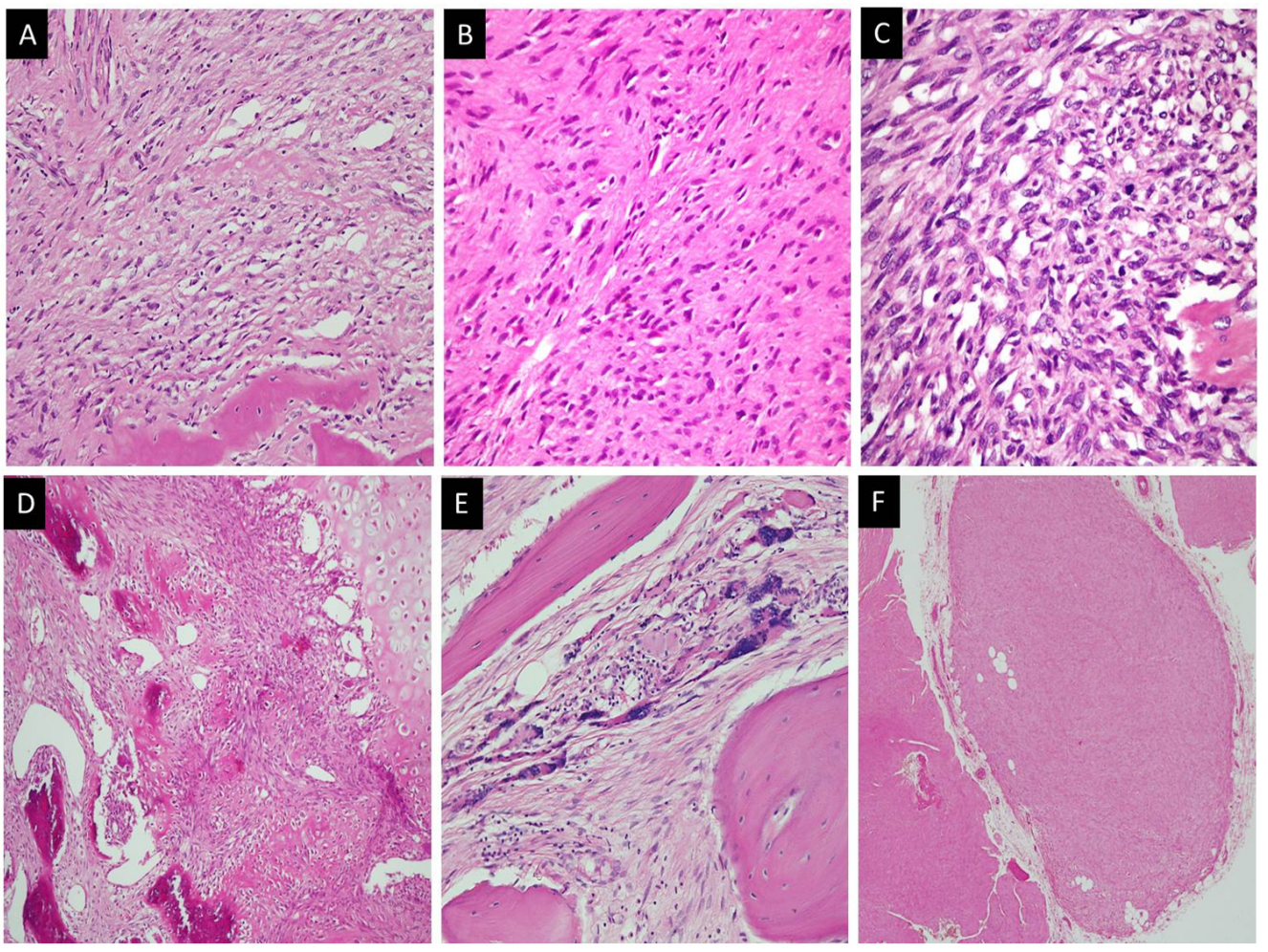

Figure 2. Soft tissue component. A) Grade 1 morphology exhibiting hypocellularity, hyalinized background, no pleomorphism and no mitoses; B) Grade 2 morphology exhibiting slightly increased cellularity, mild pleomorphism and occasional mitoses; C) Grade 3 morphology exhibiting markrdly increased cellularity, moderate to severe pleomorphism and easily appreciable mitoses; D) Soft tissue component exhibiting thin walled, dilated and ectatic (hemangiopericytoma-like) vasculature; E) Marked atrophy of entrapped skeletal muscle manifesting as nuclear bags; F) Predominence of soft tissue component manifesting as a separate soft tissue nodule devoid of bony and cartilaginous components. 


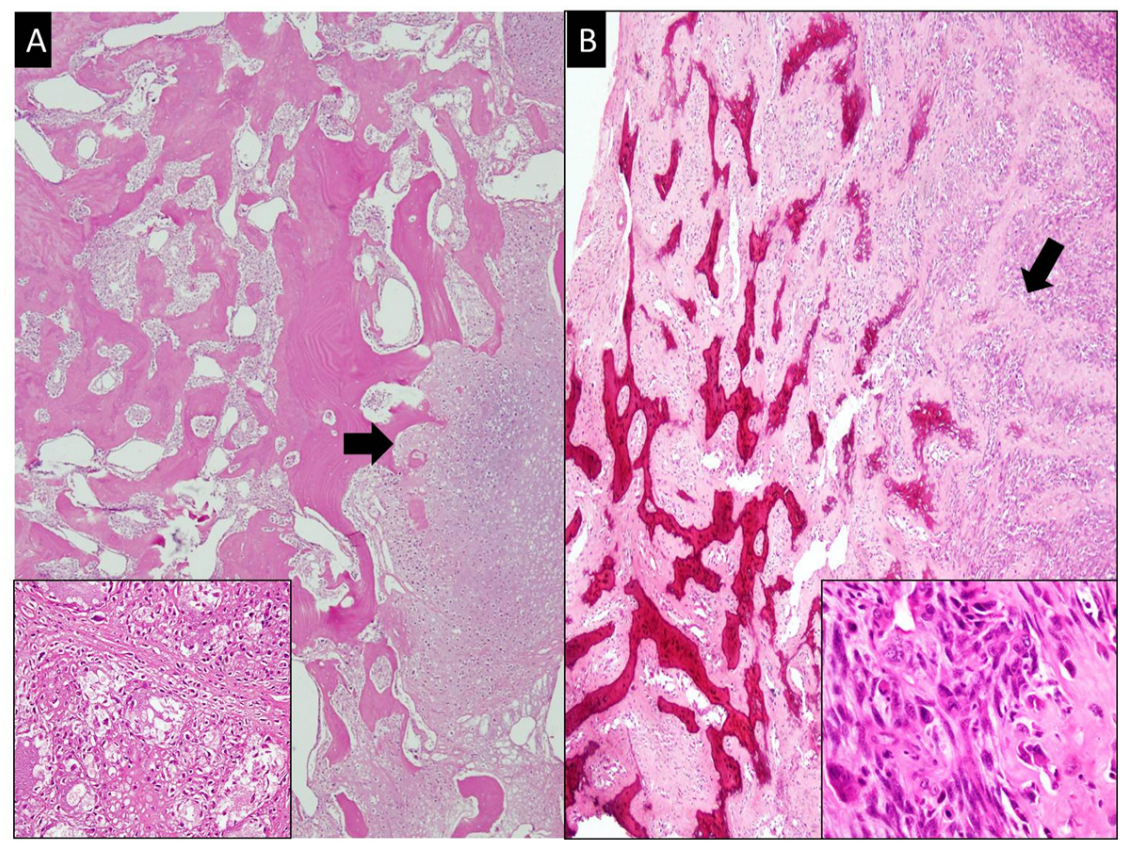

Figure 3. Dedifferentiated component. A) Chondroblastic osteosarcoma. Tumor with prominent cartilaginous background (arrow head) infiltrates into the well-formed, interconnected mature bony trabeculae of conventional PO; B) Osteoblastic osteosarcoma. Tumor with abundant malignant osteoid production (arrow head) infiltrates into the well-formed, interconnected mature bony trabeculae of conventional PO. Both insets show high grade morphology of tumor cells.
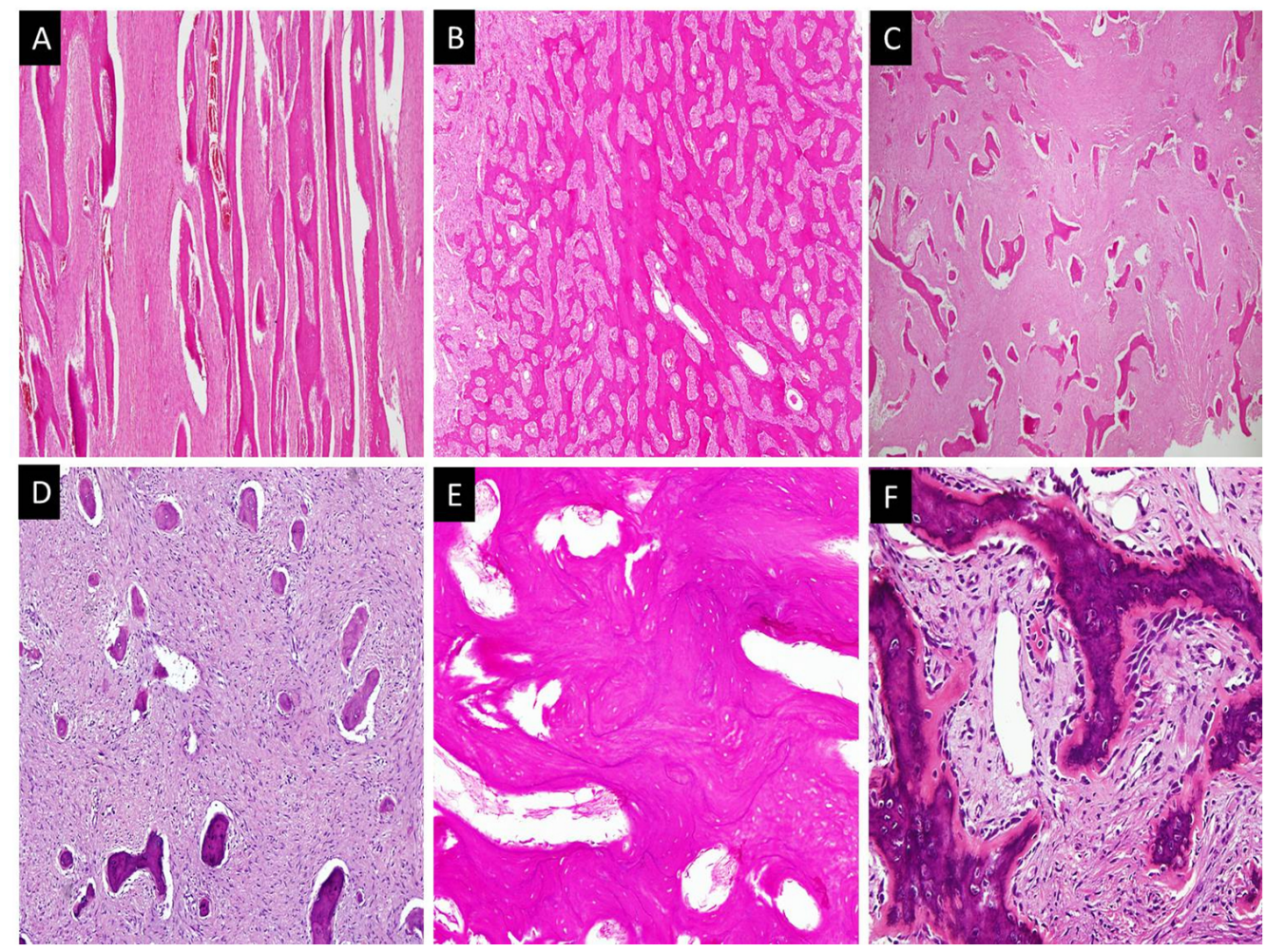

Figure 4. Bony component. A) Parallel streams of well-formed lamellar bone with intervening soft tissue component; B) Interconnected trabeculae (mosaic pattern) of mature lamellar and woven bone; $\mathrm{C}$ ) Chinese letter like bony trabeculare without osteoblastic rimming against fibrous background (fibrous dysplasia-like appearance); D) Small islands of bony against predominant fibrous background (ossifying fibroma-like appearance); E) Bony trabeculae with prominent cement lines; F) Bony trabeculae with osteoblastic rimming. 


\subsection{Bony component}

Bony component in majority of the cases comprised solely of lamellar bone, followed by a combination of lamellar and woven bone. The most common arrangement pattern was a combination of parallel streams and interconnected trabeculae. These bony trabeculae and streams were predominantly devoid of osteoblastic rimming. In 2 cases, these irregular bony trabeculae were of devoid of osteoblastic rimming and when seen scattered in the soft tissue component, imparted "fibrous dysplasia-like" appearance. In 3 cases, the bony trabeculae were heavily calcified with prominent cement lines (see Figure 4 and Table 2).

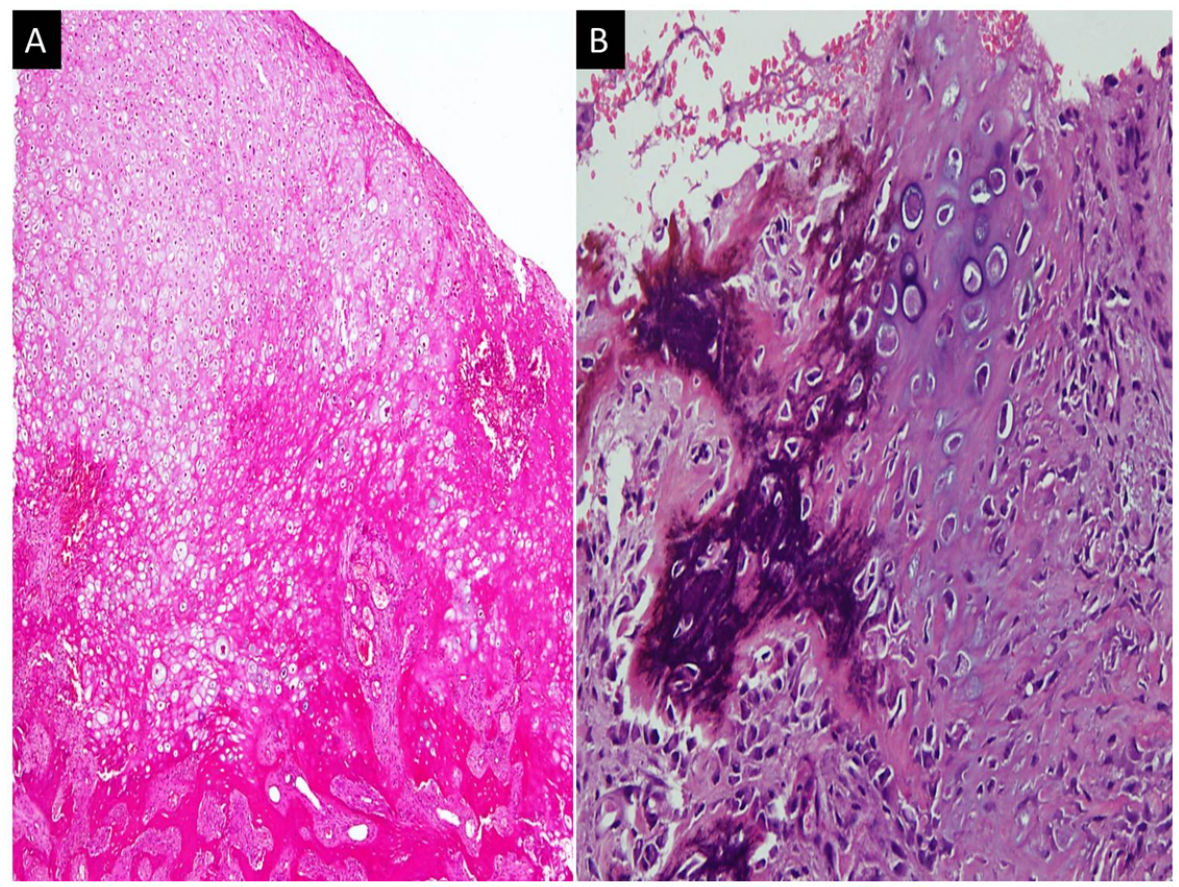

Figure 5. Cartilage component. A) Cartilage cap at the periphery of the lesion. Linear arrangement of chondrocytes (as seen in osteochondroma) is missing; B) Enchondral ossification.

\subsection{Cartilage component}

Cartilage component was seen in 9 cases of this series, 3 cases presented as a cap of hyaline cartilage and 6 presented as lobules of hyaline cartilage embedded in hyalinized stroma. Enchondral ossification was observed in all of these cases. (see Figure 5 and Table 2).

\section{Discusssion}

Age presentation, gender predilection and tumor location observed in our cohort of cases was similar to that described in literature. $13(56.5 \%)$ patients were in their 3rd decade of life and male to female ratio was 1:1.55. Distal femur was the most common site of involvement in our study as seen in $15(68.2 \%)$ cases, followed by proximal tibia in 3 $(13.6 \%)$ cases and 1 case each of humerus, fibula, radius and rib. Involvement of the ribs is quiet rare and only few cases reports are published in the literature. ${ }^{[15,17]}$ PO manifests as swelling which can be associated with pain and impaired mobility at the adjacent joint. ${ }^{[18]}$ Almost all patients of our series presented with swelling which was associated with pain in $5(27.7 \%)$ cases.

The great degree of histological variation in PO brings a number of reactive and neoplastic lesions of bony and soft tissue origin into the differential diagnosis. Typical morphological picture of $\mathrm{PO}$ comprises of well-formed bony trabeculae separated by hypocellular fibrous stroma which gradually increases in cellularity towards the cortex. Presence of both of these components is necessary to reach a definitive diagnosis and therefore, incisional biopsies become difficult to deal with, especially if one of the components is missed while sampling. Soft tissue component comprises of fascicles of spindle cells against a predominantly hyalinized background stroma which can be myxoid in few cases. Based upon the variations of cellularity, pleomorphism and mitosis, soft tissue component is graded on a scale of 1 to 3 . Ahuja SC et $a l^{[19]}$ has reported the histologic grades to correlate with the prognosis but according to Campanacci $\mathrm{M}$ et al.,$^{[3]}$ the increased metastatic rate in grade 2 and 3 tumors is attributed to increased rate of medullary involvement while local recurrence is attributed to inadequate surgical excision rather 
than tumor grade. Similarly, we also observed in our study that out of 3 recurrent cases, 2 had grade 1 and 1 had grade 2 soft tissue component while no recurrence was observed in cases with grade 3 soft tissue component. Small biopsy specimens with predominance of soft tissue component and inconspicuous bony component, Grade 1 and 2 tumors can be mistaken for lesions like desmoplastic fibroma and fibromatosis, especially when they infiltrate into surrounding muscles. On the other hand, grade 3 tumors can resemble soft tissue sarcoma such as fibrosarcoma or fibroblastic variant of osteosarcoma. ${ }^{[3,11]}$ Presence of bony component intermixed with soft tissue component helps to discriminate between the PO and soft tissue tumors while absence of malignant osteoid and surface location at radiology favors PO.

Table 2. Summary of histological features of parosteal osteosarcomas $(n=23)$

\begin{tabular}{ll}
\hline Histologic features & Expression (\%) \\
\hline Soft tissue grade & \\
Grade 1 & $9(39 \%)$ \\
Grade 2 & $8(34.7 \%)$ \\
Grade 3 & $4(17.3 \%)$ \\
Dedifferentiation & $2(8.6 \%)$ \\
Background stroma & \\
Collagenized & $21(91.6 \%)$ \\
Myxoid & $1(4.3 \%)$ \\
Both & $1(4.3 \%)$ \\
Bone quality & \\
Lamellar & $16(69.5 \%)$ \\
Woven & $2(8.6 \%)$ \\
Both & $5(21.7 \%)$ \\
Arrangement of bony trabeculae & \\
Parallel streams & $5(21.7 \%)$ \\
Interconnected trabeculae (Mosaic) & $6(26 \%)$ \\
Small islands \& separate trabeculae & $3(13 \%)$ \\
Parallel streams \& interconnected trabeculae & $9(39 \%)$ \\
Calcified bony trabeculae & $5(21.7 \%)$ \\
Osteoblastic rimming & $8(34.7 \%)$ \\
Cartilage component & $9(39 \%)$ \\
Arrangement of cartilage component & \\
Cartilage cap & $3(13 \%)$ \\
Cartilage lobules & $6(26 \%)$ \\
Grade of cartilaginous component (n=9) & \\
Grade 1 & $1(11 \%)$ \\
Grade 2 & $7(88 \%)$ \\
Grade 3 & $1(11 \%)$ \\
Enchondral ossification & $9(39 \%)$ \\
Soft tissue prominence & $5(21.7 \%)$ \\
Muscle atrophy & $4(17.3 \%)$ \\
Dilated vasculature & $3(13 \%)$ \\
\hline & \\
\hline
\end{tabular}

Arrangement of the bony trabeculae in parallel streams provides a useful diagnostic clue but it is frequently accompa- nied by "mosaic pattern" formed by interconnected bony trabeculae with prominent cement lines which can mislead to the diagnosis of osteoma or paget's disease. ${ }^{[2]}$ Only $21.7 \%$ cases of our series had characteristic parallel streams as the exclusive pattern of arrangement and $26 \%$ cases had mosaic pattern as the exclusive pattern of arrangement while the combination was the most common pattern as seen in $39 \%$ cases. The bony component can appear in both lamellar and woven forms. Moreover, it can also be present as small islands of bone and separate trabeculae embedded in fibrous stroma resembling fibro-osseus lesion such as fibrous dysplasia. The situation becomes even tougher when these trabeculae take curvilinear (chinese letter-like) appearance and lack osteoblastic rimming which was only focally observed in 8 (34.7\%) cases of this series. Adding further to the confusion, fibrous dysplasia can present as an exophytic growth (fibrous dysplaia protuberans). But the presence of an intramedullary component radiologically provides a diagnostic clue. ${ }^{[11,20]}$ Exuberant fracture callus exhibits fibroblastic proliferation and new bone formation with progressive maturation and therefore closely resemble PO. History of fracture, radiological findings and lack of well-formed bony trabeculae helps to avoid misdiagnosis. Florid reactive periostitis ossificans (FRPO) is a benign lesion which involves the periosteum and surrounding soft tissue of hands and feet bones. Histologically, it contains fibrous, cartilaginous and bony components and can therefore mimic PO, especially when this process involves long bones. Histological features which favor FRPO over PO include zonation phenomenon and presence of an inflammatory component. ${ }^{[21]}$ Myositis ossificans and bizzare parosteal ossifying periostitis (BPOP) are reactive conditions which can either involve soft tissue exclusively or periosteum along with it. Soft tissue, bony and cartilaginous components are also seen in both of these conditions but phenomenon of zonation and soft tissue component with "tissue culture-like" areas in these lesions are not seen in PO. ${ }^{[4,12]}$

The cartilage component is not integral component of PO and seen in $50 \%$ cases. It can present as a cartilage cap at the periphery in $25 \%$ cases or as hypercellular nodules of hyaline cartilage undergoing enchondral ossification. ${ }^{[11,15]}$ The grading system used for chondrosarcoma of long bones is also applied to the cartilage component of PO but it does not have any prognostic value. ${ }^{[3]}$ The cartilage component was seen in $39 \%$ cases of our series, both as cartilage cap and nodules which exhibited grade 2 morphology in 7 (88\%) of these cases. Presence of this component can lead to a frequent misdiagnosis of osteochondroma. In all 3 cases with cartilage cap, the tumors were previously misdiagnosed from other institutions as osteochondroma. Lack of the linear arrangement of chondrocytes and presence of fibrous element 
helps to distinguish between the two entities. Surface chondromas are composed of cartilaginous component and the typical bony and soft tissue component is lacking.

POs grow very slowly and have a better overall prognosis with 5 year survival of more than $90 \%$. Local recurrence (satellitosis) is a common phenomenon due to inadequate surgical resection. The incidence of medullary involvement and transformation into high grade tumors are interrelated and increase with repeated recurrence but the incidence of metastasis remains low except for dedifferentiated POs (DPOs) which behave similar to high grade sarcoma with metastatic rate of up to $50 \%$ has been observed. ${ }^{[2,3,8,10,11,16,22,23]}$ DPOs comprise $16 \%$ of POs. The sarcomatous component is mostly fibroblastic osteosarcoma, followed by fibrosarcoma, malignant fibrous histiocytoma, osteoblastic and chondroblastic osteosarcoma. ${ }^{[2,11,16]}$ We also observed dedifferentiation in 2 cases of our series. The dedifferentiated component was osteoblastic osteosarcoma in one case and chondroblastic osteosarcoma in the other case. High grade surface osteosarcomas, conventional (high grade) intramedullary osteosarcoma with extension into soft tissue and chondrosarcomas are close differentials of dedifferentiated $\mathrm{PO}$ which require extensive sampling to look for conventional (low grade) PO.

Cytogenetic analyses reveal that POs are near diploid and they contain one or more supernumerary ring chromosomes which contain amplified material of 12 q13-15 region which encodes for MDM2 and CDK4 genes. The amplification of these two genes is seen in more than $85 \%$ cases. The immunohistochemical expression of products of these genes helps in discrimination from closely mimicking fibro-osseus lesions. ${ }^{[24,25]}$ The utility of activating GNAS mutations in discriminating fibrous dysplasia from PO has been limited by a recent study which has also reported these mutations in $55 \%$ POs. ${ }^{[26]}$

Discrimination from these close differentials requires adequate sampling and radiological correlation Radiologically, these tumors are lobulated masses with irregular margins and dense mineralization. A linear radiolucent zone (String sign) is seen between the tumor and the uninvolved underlying cortex. CT and MRI scans are helpful in determining extent of disease especially in terms of medullary involvement. MRI is the diagnostic modality of choice which not only determines the extent of involvement but also discriminates high grade areas. ${ }^{[7,8]}$

En bloc resection with clear margins is recommended for low grade tumors, amputation for high grade tumors and additional chemotherapy is reserved for dedifferentiated tumors and/or those with medullary involvement. ${ }^{[13]}$ Both of the dedifferentiated tumors of our series were treated with amputation and chemotherapy. Recurrence and metastasis was not observed in both cases with follow up duration of 14 and 31 months respectively. Except for dedifferentiated cases, the patient of this series did not received the recommended treatments which can be attributed to lack of physician's knowledge about this uncommon entity, patient's illiteracy and poor socio-economic status.

In our opinion, the fibrous and bony components are the more prominent components and should be looked for in all bone surface lesion. Moreover, the presence of cartilage in surface lesions should not distract to the diagnosis and the differential diagnosis of PO should be considered in all the lesions arising from the bone surface.

\section{Conclusion}

PO manifest with variety of histologic features and therefore it should always be considered in the differential diagnosis of every lesion related to the bone surface. In depth knowledge of these histologic features help to avoid misdiagnosis. Like all other bone lesions, the radiological correlation is mandatory as it provides significant diagnostic clue especially in incisional biopsies with limited material.

\section{CONFLICTS OF INTEREST DisClOSURE}

The authors declare that there is no conflict of interest statement.

\section{REFERENCES}

[1] Papathanassiou ZH, Alberghini M, Thiesse P, et al. Parosteal osteosarcoma mimicking osteochondroma: A radio-histologic approach on two cases. Clin Sarcoma Res. 2011; 1: 2. PMid:22613734. http://dx.doi.org/10.1186/2045-3329-1-2

[2] Okada K, Frassica FJ, Sim FH, et al. Parosteal osteosarcoma. A clinicopathological study. J Bone Joint Surg Am. 1994; 76(3): 366-78. PMid:PMid:8126042.

[3] Campanacci M, Picci P, Gherlinzoni F, et al. Parosteal osteosarcoma.
J Bone Joint Surg Br. 1984; 66(3): 313-21. PMid:6586725.

[4] McClure J, Mangham DC. Surface Tumours of Bone. Diagnostic Histopathology. 2012; 18:4: 139-48. http://dx.doi .org/10.10 16/j.mpdhp. 2012.01.006

[5] Suresha S, Saifuddin A. Radiological appearances of appendicular osteosarcoma: a comprehensive pictorial review. Clin Radiol. 2007; 62: 314-23. PMid:17331824. http://dx.doi.org/10.1016/j.c $\mathrm{rad} .2006 .11 .002$

[6] Subasi M, Kapukaya A, Buyukbayram H, et al. Unusual benign bone 
lesion simulating parosteal osteosarcoma. J Orthop Sci. 2006; 11 529-32. PMid:17013744. http://dx.doi.org/10.1007/s0077 6-006-1041-x

[7] Jelinek J, Murphey M, Kransdorf M, et al. Parosteal Osteosarcoma: Value of MR Imaging and CT in the Prediction of Histologlc Grade. Radiology. 1996; 201: 837-42. PMid:8939240. http: //dx.doi.org/10.1148/radiology.201.3.8939240

[8] Azura M, Vanel D, Alberghini M, et al. Parosteal osteosarcoma dedifferentiating into telangiectatic osteosarcoma: importance of lytic changes and fluid cavities at imaging. Skeletal Radiol. 2009; 38: 685-90. PMid:19271217. http://dx.doi.org/10.1007/s0025 6-009-0672-3

[9] Bertoni F, Boriani S, Laus M, et al. Periosteal chondrosarcoma and periosteal osteosarcoma. Two distinct entities. J Bone Joint Surg Br. 1982; 64(3): 370-6. PMid:7096408.

[10] Lorentzon R, Larsson SE, Boquist L. Parosteal (juxtacortical) osteosarcoma. A clinical and histopathological study of 11 cases and a review of the literature. J Bone Joint Surg Br. 1980; 62-B(1): 86-92. PMid:6927979.

[11] Antonescu CR, Huvos AG. Low-Grade Osteogenic Sarcoma Arising in Medullary and Surface Osseous Locations. Am J Clin Pathol. 2000; 114(Suppl 1): S90-S103. PMid:11996175.

[12] Lazer A, Mertens F. Parosteal Osteosarcoma. In Fletcher CDM, Bridge JA, Hogendoorn P, Mertens F. eds. Pathology and genetics of head and neck tumours, 4th Edition. IARC Press, Lyon, France. 2013: 292-3.

[13] Murphey M, Robbin M, Flemming D, et al. From the Archives of the AFIP: The Many Faces of Osteosarcoma. Radiographics. 1997; 17: 1205-31. PMid:9308111. http://dx.doi.org/10.1148/rad iographics.17.5.9308111

[14] Samardziski M, Zafiroski G, Tolevska C, et al. Diagnostic and treatment problems with parosteal osteosarcoma. A clinical and a histological study of 7 cases and review of the literature. Radiol Oncol. 2007; 41(3): 152-60. http://dx.doi.org/10.2478/v10019-0 07-0024-7

[15] Park YK, Ryu KN. Parosteal Osteosarcoma of the Scapula. J Korean Med Sci. 1999; 14: 586-8. PMid:10576159. http://dx.doi.org /10.3346/jkms.1999.14.5.586

[16] Wold LE, Unni KK, Beabout JW, et al. Dedifferentiated parosteal osteosarcoma. J Bone Joint Surg Am. 1984; 66: 53-9. PMid:6581170.
[17] Shah A, Ma H, Sun X, et al. Primary parosteal osteosarcoma of the rib. Interact Cardiovasc Thorac Surg. 2012; 15(1): 169-70. PMid:22514259. http://dx.doi.org/10.1093/icvts/ivs081

[18] Dönmez FY, Tüzün Ü, Başaran C, et al. MRI findings in parosteal Osteosarcoma: correlation with histopathology. Diagn Interv Radiol. 2008, 14: 147-52.

[19] Ahuja SC, Villacin AB, Smith J, et al. Juxtacortical (parosteal) osteogenic sarcoma: histological grading and prognosis. J Bone Joint Surg Am. 1977; 59: 632-47. PMid:267053.

[20] Hang JF, Chen PC. Parosteal Osteosarcoma. Arch Pathol Lab Med. 2014; 138: 694-9. PMid:24786129. http://dx.doi.org/10.58 58/arpa. 2013-0030-RS

[21] Azorín D, López-Pino MA, González-Mediero I, et al. Long bone florid reactive periostitis ossificans: a case in the distal femur mimicking osteosarcoma. J Pediatr Orthop B. 2008; 17(6): 3015. PMid:18841064. http://dx.doi.org/10.1097/BPB.0b013 e328311d4b9

[22] Combalia A, Munoz-Mahamud E, Palacín A, et al. Local recurrence of a parosteal osteosarcoma 21 years after incomplete resection. Chin J Cancer. 2011; 30(12): 861-6. PMid:22059909. http://dx.doi.org/10.5732/cjc.011.10090

[23] Sheth DS, Yasko AW, Raymond AK, et al. Conventional and dedifferentiated parosteal osteosarcoma: diagnosis, treatment, and outcome. Cancer. 1996; 78: 2136-45. http: //dx.doi.org/10.1002/(SICI) 1097-0142(19961115)78: 10<2136: : AID-CNCR14>3.0.CO;2-\#

[24] Mejia-Guerrero S, Quejada M, Gokgoz N, et al. Characterization of the 12q15 MDM2 and 12q13-14 CDK4 amplicons and clinical correlations in osteosarcoma. Genes Chromosomes Cancer. 2010; 49(6): 518-25. PMid:20196171

[25] Dujardin F, Binh MB, Bouvier C, et al. MDM2 and CDK4 immunohistochemistry is a valuable tool in the differential diagnosis of low-grade osteosarcomas and other primary fibro-osseous lesions of the bone. Mod Pathol. 2011; 24(5): 624-37. PMid:21336260. http://dx.doi.org/10.1038/modpathol.2010.229

[26] Carter JM, Inwards CY, Jin L, et al. Activating GNAS mutations in parosteal osteosarcoma. Am J Surg Pathol. 2014; 38(3): $402-$ 9. PMid:24525511. http://dx.doi.org/10.1097/PAS.00000 00000000144 